\title{
PROGRAM EARLY AGROEDUCATION UNTUK SISWA SEKOLAH DASAR PADA LABORATORIUM LAPANG TERPADU FAKULTAS PERTANIAN UNIVERSITAS LAMPUNG
}

\author{
Warji \\ Jurusan Ilmu Keteknikan Pertanian, Fakultas Pertanian, Universitas Lampung, Bandar Lampung \\ Jl. Prof. Sumantri Brojonegoro No.1 Bandar Lampung 35145 \\ Penulis Korespodensi: warji1978@gmail.com
}

\begin{abstract}
Abstrak
Salah satu tujuan Laboratorium Lapang Terpadu adalah menjadi pusat pengenalan dini pertanian secara integal melalui program early agroeducation dan agroturism. Program ini menjadi salah satu pembelajaran pertanian bagi anak-anak sejak dini. Program pengabdian ini diikuti oleh anak-anak SD Insantama Bandar Lampung Kelas I. Anak-anak dikenalkan dan diajari cara mengolah tanah, menanam, menyiangi rumput, memupuk, dan memanen tanaman yang mereka tanam. Anak-anak juga diajak berkeliling Lab. Lapang Terpadu untuk mengenal tanaman-tanaman yang ada di Lab. Lapang Terpadu. Kegiatan ini berjalan dengan baik dan mampu memperkenalkan pertanian secara dini kepada anak-anak serta dapat menumbuhkan kecintaan anak terhadap bidang pertanian tanpa mengganggu pelayanan Lab. Lapang Terpadu terhadap pelaksanaan praktikum dan penelitian mahasiswa dan dosen. Anak-anak mengikuti program ini dengan senang dan interaktif, walaupun kegiatan yang dilakukan cukup melelahkan dan berkutat dengan lumpur. Hal ini menunjukkan bahwa fungsi kegiatan pengabdian ini sebagai aktivitas rekreatif bagi anak-anak juga didapatkan sehingga program early agroeducation dan agroturism dapat tercapai dengan baik.
\end{abstract}

Kata kunci: Early Agroeducation, Agroturism, Laboratorium Lapang Terpadu, Pertanian.

\section{Pendahuluan}

Laboratorium Lapang Terpadu, di bawah Fakultas Pertanian Universitas Lampung, telah dibentuk dengan SK REKTOR Nomor: 201/H26/RT/2009. Dengan keluarnya SK Rektor tersebut, maka Laboratorium Lapang Terpadu mulai operasinal, namun pelayanan yang diberikan masih sangat terbatas menginat lahan yang luasnya 6,7 Ha ini sebagian besar berupa semak belukar. Tahun 2010 Lab. Lapang Terpadu pertama mulai dibuka, dibangun dan dikelola.

Laboratorium Lapang Terpadu, Fakultas Pertanian Universitas Lampung berkontribusi pada penyediaan lahan dan sarana praktikum yang dapat memecahkan persoalan-persoalan tentang aspek peningkatan mutu praktikum dan penelitian. Laboratorium Lapang Terpadu juga berperan menjadi show windows agricultural sehingga mampu menampilkan gambaran umum tentang pertanian secara integral dan menyeluruh. Bahkan
Laboratorium ini juga berupaya meningkatkan minat generasi muda terhadap bidang pertanian melalui program early agroeducation, dimana hal ini telah menjadi salah satu tujuan Laboratorium (LLT, 2012).

Salah satu tujuan Laboratorium Lapang Terpadu adalah menjadi pusat pengenalan dini pertanian secara integal melalui program early agroeducation dan agroturism. Program ini menjadi salah satu pembelajaran pertanian bagi anak-anak sejak dini. Program ini dapat diikuti oleh anak-anak TK dan SD. Anak-anak akan dikenalkan dan diajari cara mengolah tanah, menanam, menyiangi rumput, memupuk, dan memanen tanaman yang mereka tanam, bahkan menikmati hasil panen mereka di tengah-tengah kebun yang rindang. Anak-anak juga diajak berkeliling Lab. Lapang Terpadu untuk mengenal tanaman-tanaman yang ada di Lab. Lapang Terpadu. Kegiatan ini 
diharapkan dapat menumbuhkan kecintaan anak terhadap bidang pertanian.

Potensi Lab. lapang terpadu dalam mendukung kegiatan early agroeducation sangat besar. Beberapa potensi disajikan pada Gambar berikut:

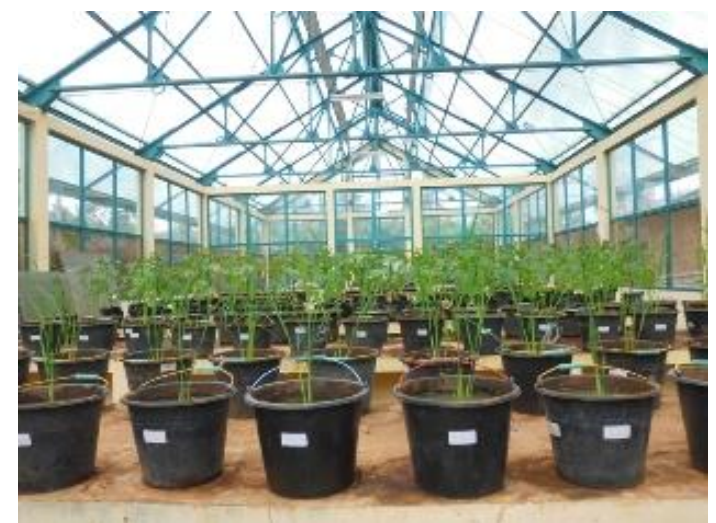

Gambar 1. Rumah kaca

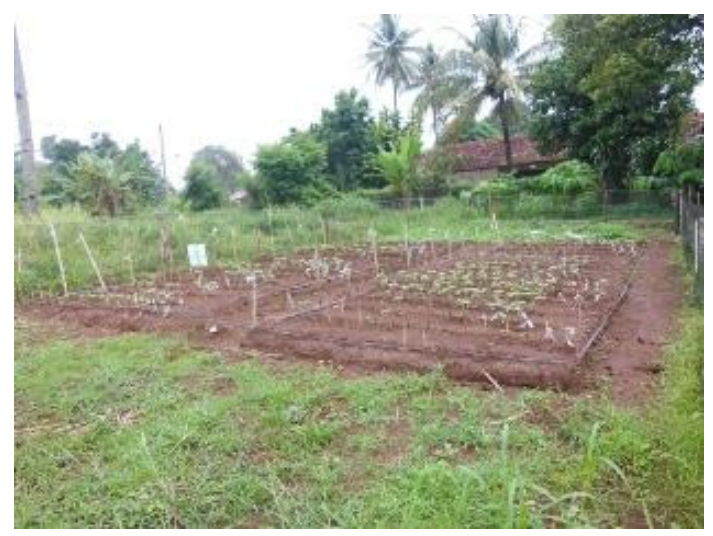

Gambar 2. Lahan untuk menanam

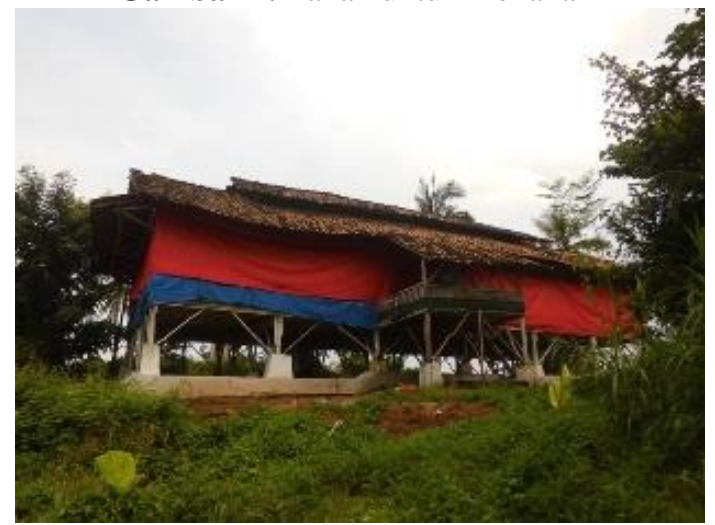

Gambar 3. Kandang ayam

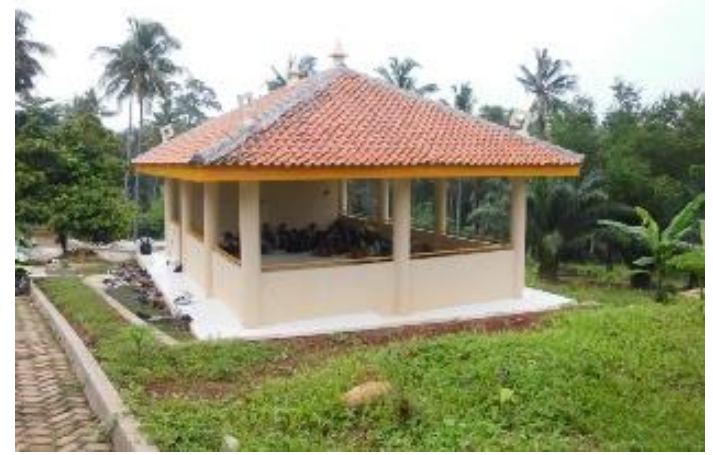

Gambar 4. Saung tempat pertemuan

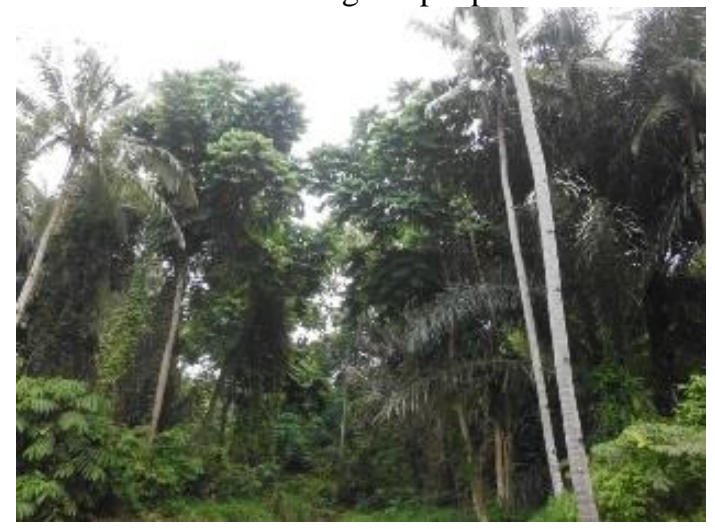

Gambar 5. Areal tanaman hutan

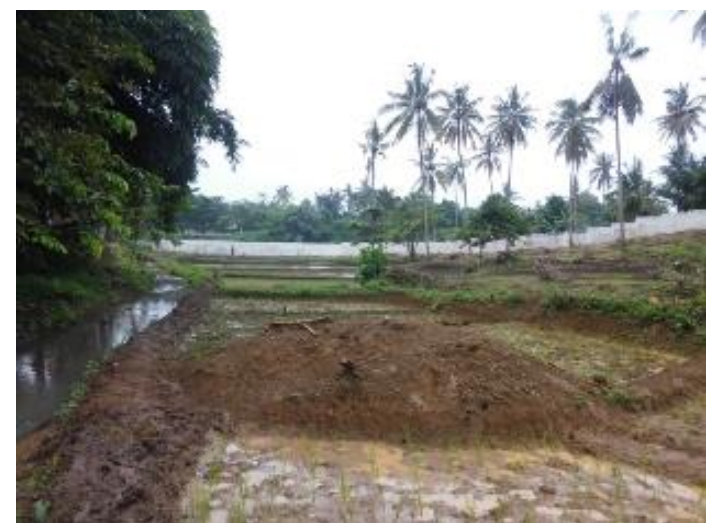

Gambar 6. Lahan sawah

Agroschooling bertujuan untuk mengenalkan dunia pertanian dan lingkungan alam sekitar kepada anak-anak khusunya anak-anak sekolah dasar. Agroschooling dikemas dalam bentuk kegiatan yang beda, tidak formal, kratif dan inovatif sehingga anak-anak bisa bermain sambil belajar. Pertama-tama anak-anak diajarkan tentang dunia pertanian melalui video unik pertanian bahkan yang dikemas dalam film kartun. Kemudian diajarkan juga proses menanam tanaman 
SAKAI SAMBAYAN — Jurnal Pengabdian kepada Masyarakat

mulai dari awal hingga panen melalui gambargambar yang berbentuk puzzle sehingga mereka tidak bosan saat materi di kelas. (Ikhsan, 2012).

Anak-anak diajak langsung untuk berkebun atau menanam mulai dari pembibitan, pengolahan tanah di pot yang kecil, namun yang berbeda adalah pot mereka diberi nama mereka dan kelompok yang berbeda-beda serta juga dikompetisikan sampai panen nanti mana yang rajin dalam merawat dan menyiram tanaman. Ini juga sederhana karena anak-anak akan mulai berkutat dengan tanah sehingga "tidak takut kotor" (Ikhsan, 2012).

Kemudian selama anak-anak menunggu tanaman mereka tumbuh, mereka diajarkan juga pengetahuan mengenai lingkungan seperti memungut sampah di halaman sekolah ataupun menggunakan tumbler sebagai wadah minum ke sekolah. Jika program ini berkelanjutan bukan tidak mungkin ke depannya anak-anak Indonesia mau menjadi (petani) (Ikhsan, 2012).

Penyadaran generasi muda akan pentingnya sektor pertanian sepertinya sangat terlambat jika harus menunggu mereka untuk memilih kuliah di bidang disiplin ilmu pertanian. Sebaliknya, pendidikan dan pemahaman akan pentingnya sektor pertanian itu perlu diterapkan sejak usia dini, sejak sekolah dasar. Pendidikan pertanian sejak dini merupakan sesuatu yang esensial bagi sebuah Negara yang memiliki gelar 'Negara agraris'. Pendidikan pertanian harus diperkenalkan pada anak-anak sejak mereka mengenal begitu banyak sektor yang bekerja membangun pertumbuhan ekonomi bangsanya (Muharamsyah, 2013).

Pendidikan pertanian sejak dini akan mempermudah inovasi teknologi di bidang pertanian serta pemahaman dasar tentang konsep pertanian itu sendiri. Bukankah kita sudah mafhum akan peribahasa "belajar di masa muda seperti mengukir di atas batu" hal ini memberi penjelasan mengapa saat ini para penyuluh pertanian masih susah payah memberikan pendidikan teknis pada petani yang kebanyakan berada di pelosok desa di sentra pertanian, karena dahulu sumberdaya- sumberdaya manusia yang potensial ini tidak pernah mengenyam pendidikan teknis pertanian dasar itu, atau memang dulu kita belum sadar akan pentingnya pendidikan pertanian (Muharamsyah, 2013).

Penyuluh pertanian tidak akan susah payah memberikan pemahaman dasar mengenai konsep pertanian berkelanjutan pada petani, jika mulai dari saat ini generasi muda kita, khususnya mereka yang ada di usia sekolah sudah mengetahui pentingnya sektor pertanian untuk pembangunan ekonomi lebih dini, pemahaman ini akan terpatri dalam benak anak-anak yang kelak, meski memang tidak akan semuanya, akan memegang nasib pertanian Indonesia di masa depan (Muharamsyah, 2013).

Salah satu program untuk memperkenalkan pertanian adalah menanam padi. Pertanian padi merupakan salah satu pertanian yang luas yang ada di Indonesia, hal ini perlu diketahuai dan didukung karena merupakan aktivitas untuk mempertahankan swasembada pangan nasional.

Cara menanam padi yang baik akan menentukan keberhasilan budidaya. Sekalipun cara menanam padi sawah dianggap budidaya mudah akan tetapi kegagalan panen masih sering terjadi hampir di seluruh wilayah di Indonesia, apalagi ketika tanaman padi terserang hama tikus, sudah bisa dipastikan hasil panen menurun sangat signifikan bahkan seringkali menyebabkan puso. Sekalipun mudah, jika kita menguasai teknik menanam padi dengan baik niscaya akan meningkatkan produktivitas pertanaman. Berikut ini akan dibahas mengenai bagaimana cara menanam padi sawah beserta cara pengendalian hama dan penyakit pengganggu tanaman.

Membuat persemaian merupakan langkah awal dalam budidaya. Pembuatan persemaian memerlukan persiapan sebaik-baiknya, sebab benih di persemaian akan menentukan pertumbuhan tanaman, oleh karena itu persemian harus benarbenar mendapat perhatian, agar harapan untuk mendapatkan bibit padi sehat sekaligus subur dapat tercapai. Hal yang perlu diperhatikan adalah penggunaan benih padi unggul bersertifikat, 
SAKAI SAMBAYAN — Jurnal Pengabdian kepada Masyarakat

dengan kebutuhan benih 25-30 kg/ha. Lokasi persemaian diusahakan pada tanah subur dengan intensitas cahaya matahari sempurna. Buat bedengan berukuran lebar $1 \mathrm{~m}$, panjang $4 \mathrm{~m}$, tinggi 20-30 cm. Pada lahan seluas 1 hektar dibutuhkan 4 bedengan. Untuk menghindari serangan hama tikus, sebaiknya tempat persemaian dikelilingi pagar plastik. Berikan pupuk NPK sebanyak $1 \mathrm{~kg}$ untuk 4 bedengan. Benih padi yang telah direndam selama 1 malam siap ditebar.

Bibit padi siap pindah tanam saat berumur 18 hari. Sebelum ditanam, rendam bibit yang telah dicabut dalam larutan insektisida berbahan aktif karbofuran selama 2 jam dengan konsentrasi 1 gr/liter air. Daun bibit dibiarkan utuh, tidak dipotong seperti kebiasaan petani. Saat melakukan penanaman, lahan dalam kondisi macak-macak, tidak perlu tergenang air. Penanaman padi dilakukan dengan jumlah satu tanaman per titik tanam, menggunakan sistem jajar legowo 2-1, jarak $15 \mathrm{x} 25 \mathrm{~cm}$, lebar barisan legowo $50 \mathrm{~cm}$. Keuntungan cara menanam padi sawah menggunakan sistem ini adalah memberikan ruang cukup untuk pengaturan air, mengoptimalkan cahaya matahari, pengendalian hama dan penyakit juga lebih mudah, serta pemupukan lebih berdaya guna (Kurnianti, 2013). Cara menanam padi inilah yang menjadi acuan untuk melakukan program pengenalan pertanian kepada anak-anak melalui aktivitas menanam padi.

Kegiatan pengabdian ini bertujuan memperkenalkan pertanian kepada anak-anak Sekolah Dasar. Manfaat kegiatan ini adalah terbukanya wawasan anak-anak Sekolah Dasar tentang pertanian, sehingga muncul kecintaan mereka terhadap bidang pertanian, bahwa bidang pertanian adalah menyenangkan sehingga mereka muncul penghargaanya terhadap bidang pertanian dan muncul pula cita-cita untuk terjun di bidang Pertanian. Dalam jangka panjang juga merupakan promosi Fakultas Pertanian Universitas Lampung untuk menjadi minat kuliah mereka.

\section{Bahan dan Metode}

\section{A. Khalayak Sasaran}

Khalayak sasaran kegiatan pengabdian ini adalah Siswa-siswa SDIT Insantama kelas I. selain itu kegiatan ini juga ditujukan kepada Guru Kelas atau Guru Pendamping, dengan harapan para guru bisa menjelaskan dan mempromosikan bidang pertanian kepada anak Sekolah Dasar.

\section{B. Metode pelaksanaan}

Metode pengabdian berupa (i) penjelasan umum di dalam kelas tentang profil Lab.Lapang, menjelaskan rute perjalan di dalam Lab. Lapang, menjelaskan cara menanam padi (tema kegiatan), (ii) memandu anak-anak SD dan Guru berkeliling Lab. Lapang sesuai dengan rute yang ditentukan sambil menjelaskan tanaman, kegunaan dan lainlain yang ada di sepanjang rute, dan (iii) memberikan pelatihan menanam padi.

\section{Keterkaitan program}

Salah satu misi Laboratorium Lapang Terpadu adalah Menjadi pusat pengenalan dini pertanian secara integal melalui program early agrieducation dan agroturism, sehingga relevan diadakan program early agrieducation kepada anak-anak SD. Laboratorium Lapang juga memiliki daya dukung Fasilitas, lahan, tanaman dan penjadwalan kegiatan praktikum, penelitian serta ujicoba produksi. Sehingga pelaksanaan program early agrieducation dapat disinergikan dengan kegiatan rutin yang ada di Laboratorium Lapang Terpadu tanpa mengganggu aktivitas di dalamnya. Sementara mitra kegiatan program early agrieducation ini adalah SDIT Insantama Bandar Lampung, sekolah ini dipilih kerena salah salah satu kegiatan siswa dalam membekali soft skill-nya adalah aktivitas Farming. Sehingga program ini dapat berjalan dengan saling bersinergi.

\section{Hasil dan Pembahasan PKM}

\section{A. Pelaksanaan kegiatan pengabdian}

Pengabdian kepada masyarakat ini berjalan dengan baik dan sesuai dengan rencana. Proses 
yang pertama dilakukan adalah perumusan sosialaisasi program ke SDIT Insantama Bandar Lampung, untuk mengatur jadwal pelaksanaan program early agroeducation sesuai dengan kegiatan Farming bagi siswa. Setalah disepakati waktu untuk pelaksanaan prgram maka dilakukan penyiapan Fasilitas Lab. lapang Terpadu yang diperlukan untuk menjalankan program.

Tahap selanjutnya adalah pelaksanaan Program Early agroeducation, dalam pelaksanaan ini ada 3 bagian aktivitas utama (i) penjelasan umum (ii) memandu anak-anak SD dan Guru berkeliling Lab. Lapang dan (iii) memberikan pelatihan menanam padi. Penjelasan umum tentang Lab. Lapang Terpadu disampaikan oleh Warji, S.TP., M.Si., selaku ketua Lab. Lapang Terpadu. Pada penjelasan ini siswa-siswa sangat antusias mengikuti penjelasan, bahkan tidak sungkansungkan mereka menyeletuk untuk bertanya, hal ini menunjukkan terjadi interaksi yang baik selama proses penyampaian materi.

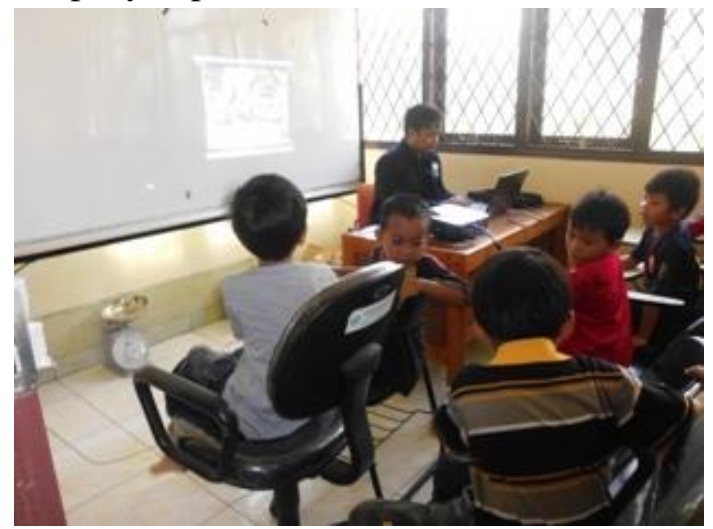

Gambar 7. Penjelasan oleh Kepala Lab. Lapang Terpadu

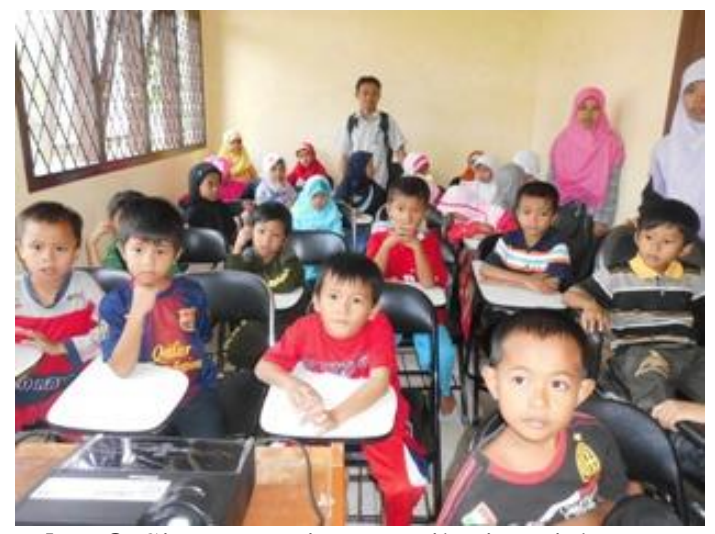

Gambar 8. Siswa antusias mengikuti penjelasan materi

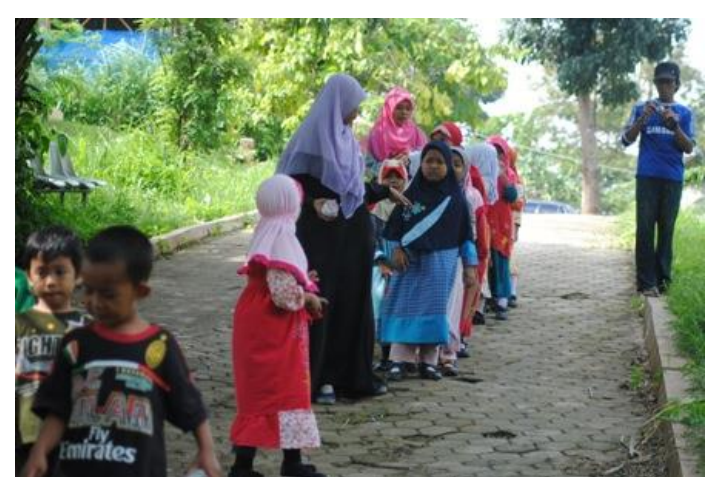

Gambar 9. Jalan kaki keliling Lab. Lapang

Kegiatan memandu anak-anak SD dan Guru Pendamping berkeliling Lab. Lapang Terpadu dipandu langsung oleh Kepala Lab. Lapang Terpadu dibantu oleh Pranata Lab. Rute keliling meliputi areal pertanaman praktikum mahasiswa yang berupa tanaman pangan, tanaman hortikultura dan perkebuanan, selain itu juga dikenalkan pohonpohon tanaman keras yang ada di Lab. Lapang Terpadu. Siswa juga dikenalkan tentang ikan yang ada di kolam dan ternak yanga ada di kandang yang bearda di Lab. Lapang Terpadu. Semua peserta sangat antusias dan tidak mengeluh kelelahan walaupun kondisi laboratorium naik dan turun.

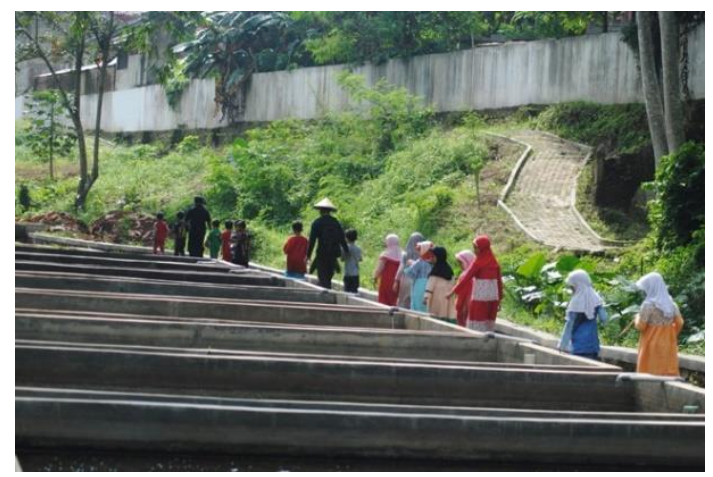

Gambar 10. Mengitari kolam ikan 


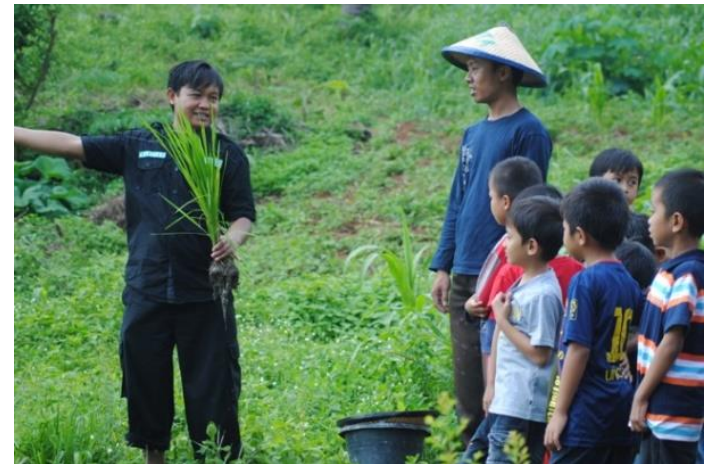

Gambar 11. Penjelasan cara menanam padi

Tahap terakhir adalah memberikan pelatihan menanam padi bagi Siswa Kelas I SDIT Insantama Bandar lampung, Warji, S.TP., M.Si. terlebih dahulu memberikan memberikan penjelasan tentang cara menanam padi secara praktis, dan memastikan semua siswa dapat menanam padi. Siswa dipandu untuk mencabut bibit dipersemaian, kemudian dipandu menanam di areal yang telah disiapkan, tampak semua siswa dengan suka-ria terjun ke lumpur untuk menanam padi.

Bahkan di luar dugaan bahwa ternyata anakanak sangat menyukai menanam sambil bermain lumpur, menangkap cacing dan orong-orong yang ada di lumpur sawah.

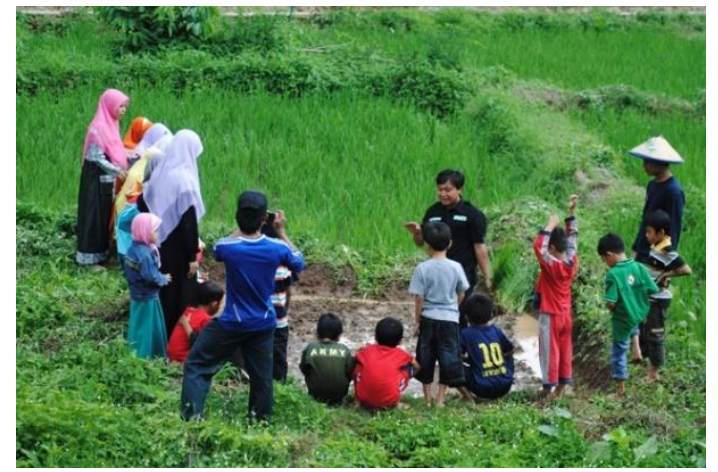

Gambar 12. Siswa antusias mengikuti instruksi yang disampaikan Kepala Lab.

Lapang terpadu

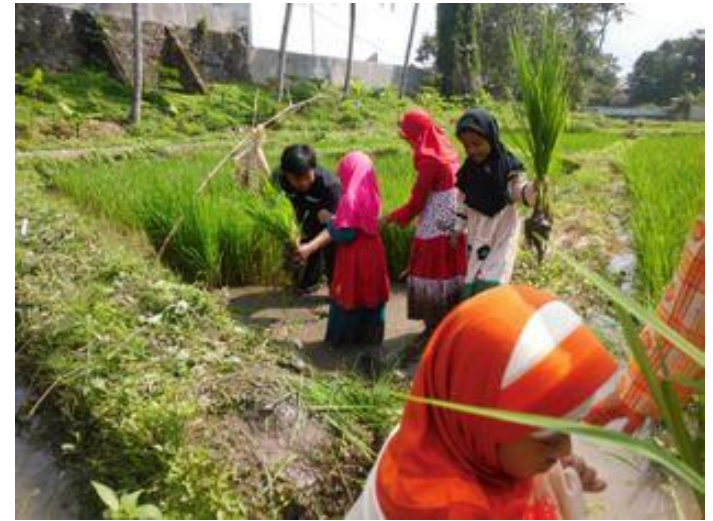

Gambar 13. Siswa mengambil bibit padi

\section{B. Evaluasi kegiatan pengabdian}

Evaluasi program early agroeducation ini dilakukan secara kualitaif didasarkan atas respon peserta program, guru pendamping, pranata laboratorium dan pengguna Lab. Lapang Terpadu. Siswa-siswa SDIT Insantama Bandar Lampung kelas I sebagai peserta program pengenalan pertanian sejak dini ini sangat senang, hal ini tampak dari ekspresi mereka, mereka sangat antusias mengikti penjelasan di dalam kelas, penjelasan selama keliling Lab. Lapang Terpadu dan mereka sangat senang masuk ke lumpur untuk menanam padi, tidak ada yang ragu-ragu untuk mencebur ke dalam lumpur sawah, bahkan ada siswa yang sangat senang ketika dapat menangkap cacing di lumpur sawah.

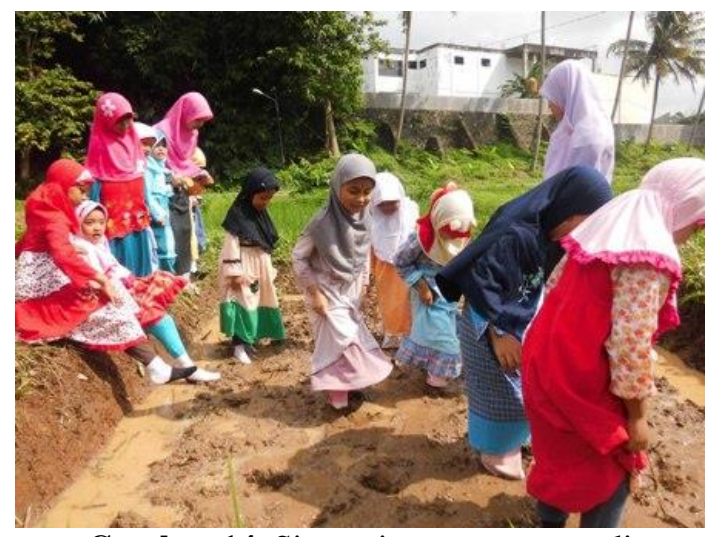

Gambar 14. Siswa siap menanam padi 


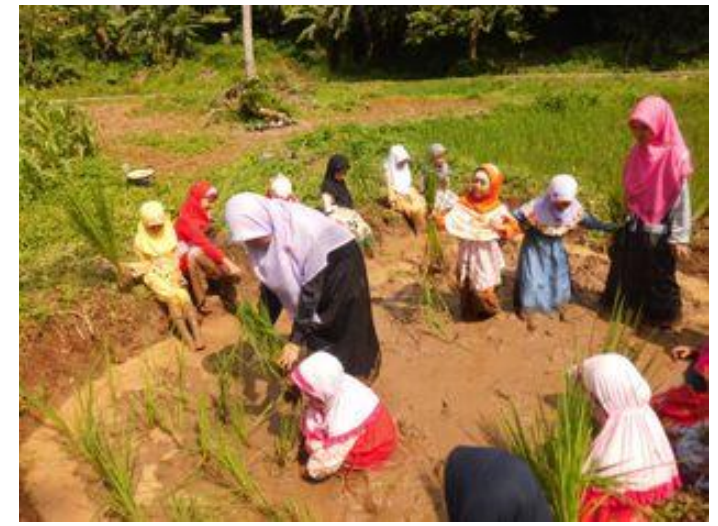

Gambar 15. Anak-anak antusias menanam padi

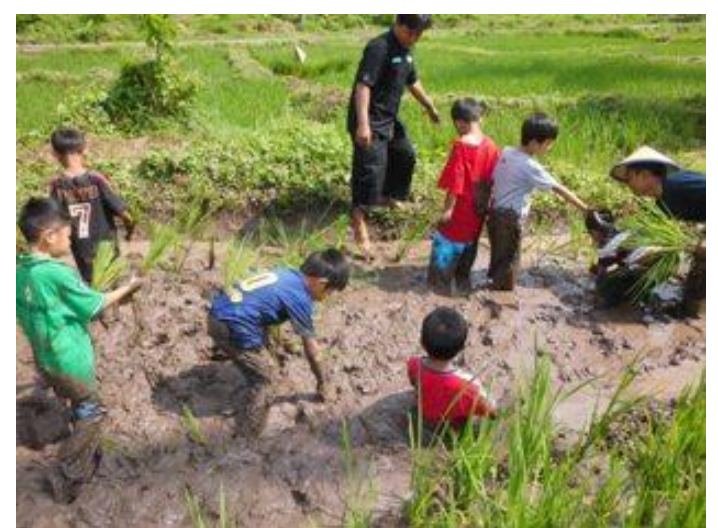

Gambar 16. Siswa semangat menanam padi di areal berlumpur

Respon guru pendamping juga baik, mereka sangat mendukung program ini bahkan mereka merasa senang karena program Farming bagi siswa kelas I SD bisa terlaksana dengan sangat baik melalui kerjasama program early agroeducation. Sementara prananata Laboratorium juga tidak merasa keberatan dengan adanya tugas tambahan untuk menyiapkan fasilitas dan areal tempat menanam padi.

Pengguna laboratorium juga tidak merasa terganggu, karena program ini diadakan disela-sela kegiatan praktikum yang biasanya dilakukan sore hari. maka secara umum program early agroeducation ini dapat terlaksana dengan baik tanpa mengganggu aktivitas Lab. lapang Terpadu.

\section{Kesimpulan:}

Kegiatan early agroeducation ini dapat berlajan lancar, anak-anak sangat antusias mengikuti program ini sehingga program untuk memperkenalkan pertanian kepada anak-anak berhasil dengan baik. Dukungan terhadap program ini sangat baik, baik dari guru dan pranata Laboratorium. Kegiatan ini juga tidak mengganggu proses praktikum dan penelitian dosen dan mahasiswa yang ada di Lab. Lapang Terpadu.

\section{Ucapan Terima Kasih}

Ucapan terima kasih disampaikan pada Fakultas Pertanian Universitas Lampung yang telah membiayai kegiatan pengabdian ini melalui progran hibah DIPA FAKULTAS PERTANIAN. Ucapan terima kasih disampaikan kepada Sigit Prio Widodo dan Rajino atas bantuannya dalam memandu dan menyiapkan lahan untuk menanam padi di Lab. Lapang Terpadu.

\section{Daftar Pustaka}

Ikhsan, G. (2012). Pendidikan Pertanian untuk Anakanak (Masih) Ada. http://edukasi.kompasiana.com/2012/12/29/pendi dikan-pertanian-untuk-anak-anak-masih-ada-514859.html

Kurnianti, N. (20130. Buwadidaya Tanaman Padi Sawah. http:// www.tanijogonegoro.com/ 2013/04/budidaya-tanaman-padi -sawah..html

Laboratorium Lapang Terpadu (LLT) Fakultas Pertanian Universitas Lampung. (2012). Rencana Strategis Laboratorium Lapang Terpadu Fakultas Pertanian Universitas Lampung.

Muharamsyah, H.A. (2013). Pendidikan Pertanian, Celah Kecil Menuju Pembangunan yang Paripurna. International Association of Students in Agricultural and Related Sciences Local Committee Padjadjaran University.

Palenewen, E. (2012). Pengembangan Model Pembelajaran Sains Melalui Bermain di Taman Kanak-Kanak. Jurnal Pendidikan Anak Usia Dini. Vol 6. No.2. 